\title{
The Mediating Effect of Internal Integration on the Relationship between Supply Chain Integration and Operational Performance: Evidence from Moroccan Manufacturing Companies
}

\author{
Mohamed Errassafi iD, Hassan Abbar iD, Zahra Benabbou (iD \\ University of Hassan 1er (Morocco) \\ errassafimohamed82@gmail.com,abbarhassan@hotmail.com,benabbou@gmail.com
}

Received: November 2018

Accepted: March 2019

\begin{abstract}
:
Purpose: This paper aims to explain the direct effect of supply chain integration on operational performance of manufacturing companies and the mediating effect of internal integration on the relationship between external integration and operational performance.

Design/methodology/approach: From an organizational capabilities perspective we consider internal integration as a set of intra-organizational capabilities and customer integration and supplier integration as a set of inter-organizational capabilities. In the basis of a sample of 75 Moroccan manufacturing companies, we used PLS - Structural Equation Modeling to study the direct effect of customer integration, internal integration and supplier integration on operational performance of manufacturers and to analyze the mediating effect of internal integration.
\end{abstract}

Findings: The results show that customer integration, internal integration and supplier integration are all positively and significantly related to operational performance of the manufacturer and internal integration mediates relationship between costumer integration and operational performance but not relationship between supplier integration and operational performance.

Research limitations/implications: This study focuses on a set of best practices for integrating flows and business processes that industrial companies need to implement in order to create value for final consumer and show how to use internal integration practices to benefit more from external integration.

Originality/value: The result of this study contributes to the literature on supply chain integration by analyzing the effect of interaction between internal and external integration on the operational performance towards an organizational capabilities perspective in a specific Moroccan industrial context.

Keywords: supply chain integration, performance, mediating effect, Morocco

\section{To cite this article:}

Errassafi, M., Abbar, H., \& Benabbou, Z. (2019). The mediating effect of internal integration on the relationship between supply chain integration and operational performance: Evidence from Moroccan manufacturing companies. Journal of Industrial Engineering and Management, 12(2), 254-273. https://doi.org/10.3926/jiem.2794 


\section{Introduction}

The inter-organizational relations between firms have marked more and more the literature these recent years (Barratt \& Barratt, 2011; Cousins \& Menguc, 2006; Flynn, Huob \& Zhaod, 2010; Liu, Luo \& Liu, 2009; Ryan, Emond \& La Montagne, 2014; Williams, Roh, Tokar \& Swink, 2013; Zhao, Huo, Selen, Hoi \& Yeung, 2011). These inter-organizational relationships include different levels and types of interaction between firms within the same supply chain. As part of this relationship, firms exchange and share information upstream and downstream of the chain in order to enhance performance (Towers \& Burnes, 2008).

Supply chain is viewed as network consisting of nodes and links. A node is an establishment (suppliers, manufacturers, customers) which is an agent that has the ability to make decisions and maximize its own gain within the parameters in which it operates in the supply chain and Links represent transactions consisting of the flow of materials, information, and/or finance between nodes (Carter, Rogers \& Choi, 2015). A firm as a partner in the supply chain must be more integrated both internally and externally. This involves more integration of information systems, more collaboration and more information sharing within the firm (internal integration), with their suppliers (supplier integration) and with their customers (customer integration).

Several empirical researches had shown that there is a significant and positive relationship between the level of integration of the supply chain and the firm performance (Alfalla-Luque, López \& Dey, 2013; Fabbe-Costes \& Jahre, 2008; Giménez \& Ventura, 2005; Huo, 2012; Huo, Zhang \& Zhao, 2015; Irani, 2014; Sahin \& Robinson, 2005; Yu, Jacobs, Enns \& Enns, 2013; Zhao, Feng \& Wang, 2015). However, incomplete and evolving conceptualizations made by these authors have led to inconsistent findings about this relationship.

According to Fabbe-Costes and Jahre (2008), the analysis of the relationship between supply chain integration and performance depends on three aspects: The way in which integration is apprehended and measured, the way in which performance is apprehended and measured and the nature of the relationship that exists between these two variables. There are three dimensions of supply chain integration that may affect firm performance: customer integration, internal integration and supplier integration. A set of techniques and practices of integration exist in each dimension of integration: information integration, coordination and collaboration. There is also a strategic and operational level in supply chain integration (Saeed, Malhotra \& Grover, 2005).

Despite the abundance of literature on the benefits of all dimensions of supply chain integration, there is always few researches that studies the effects of interaction between customer integration, internal integration and supplier integration on the firm performance.

Through an organizational capabilities perspective (Grant, 1996; Teece, Pisano \& Shuen 1997), supply chain integration can be viewed as a set of intra- and inter-organizational capabilities. In other words, internal integration involves more competencies on information integration and collaboration within the firm and external integration is focused on all capabilities of the firm to integrate and share information and collaborate with suppliers and customers within all the supply chain.

Morocco has strengthened its global positioning in some world global businesses. So the supply chain integration has become a major challenge for manufacturing companies, especially those operating in complex supply chains (automotive, aerospace, electronics and Textile manufacturing). Indeed, the scattering of production processes around the world as generated by outsourcing strategies implies more coordination between all partners off the chain. This coordination needs more integration of the material and information flows and strategic collaboration to increase synchronization within the supply chain.

We except that a manufacturer firm may increase its operational performance by increasing the level of integration with its customers and suppliers, but this integration requires a collaboration and information sharing inside the firm. From an organizational capabilities approach we will show by an empirical study (based on PLS - Structural Equation Modeling) how the three dimensions of integration affect the operational performance of the Moroccan manufacturer and how internal integration mediates the relationship between both supplier and customer integration and operational performance. 
Section 2 of the paper presents the relevant literature and research hypotheses. The methodological approach is developed in section 3. In the fourth section, we will present and analyze the results and we will discuss these results in section 5. Finally, section 6 includes limitations of the study and implications for future research.

\section{Theoretical Framework and Hypothesis Formulation}

\subsection{Supply Chain Integration Dimensions}

The construct of supply chain integration is relatively recent as a research issue although there were several studies that examined the relationships of cooperation and collaboration between partners within a supply chain (Comelli, Fenies \& Tchernev, 2007; Greis \& Kasarda, 1997; Mentzer, Foggin \& Golicic, 2000; Spekman, Kammuf \& Myhr, 1998; Xue, Wang, Shen \& Yu, 2007). This construct is still difficult to understand because of its multidimensional nature. The construct must take into account both the level of integration (upstream, internal and downstream) and the nature of this integration (integration of information systems, information sharing, strategic collaboration and operational coordination).

According to Van der Vaart, Giménez and Donk (2007), SCI is "the degree to which a manufacturer strategically collaborates with its supply chain partners and collaboratively manages intra- and inter-organization processes. The goal is to achieve effective and efficient flows of products and services, information, money and decisions, to provide maximum value to the customer at low cost and high speed".

This definition includes several important elements. First of all, the importance of strategic collaboration between partnerships in order to achieve mutually beneficial strategic goals, it is based on mutual trust, contract duration, sharing of information and collaboration in conflict resolution (Flynn et al., 2010). The second component corresponds to coordination of operational process within the organization and between partners. Through a dyadic perspective, integration can be internal which refers to integration of flows and process and collaborating within the focal firm and external (customer integration and supplier integration) which is the degree to which a manufacturer partners with its external partners to structure inter-organizational strategies, practices and processes into collaborative, synchronized processes (Flynn et al., 2010). This multidimensional nature of the integration process involves the need to investigate how these dimensions of integration work separately and jointly.

In the first SCI's researches, authors who have specially studied the impact of integration on firm's performance, have used the construct as single dimension (Dong, Carter \& Dresner, 2001; Frohlich \& Westbrook, 2001; Kannan \& Tan, 2005) before finding that the best way to identify the phenomenon is to study it in all its dimensions (Huo et al., 2015; Huo, Qi, Wang \& Zhao, 2014; Wong, Boon-itt \& Wong, 2011; Wong, Lai \& Bernroider., 2015; Yu et al., 2013). Integration researches should, in fact, take into account all the three levels: "supplier integration", "internal integration" and "customer integration" as recommended also by Fabbe-Costes and Jahre (2008).

\subsection{Supply Chain Integration As an Organizational Capabilities}

According to Kusunoki, Nonaka and Nagata (1998), there are various definitions for the concept of organizational capabilities, but most research agree that organizational capabilities are not easily obtainable in the marketplace and are difficult to copy; they are accumulated through long-term and continuous learning and have the potential to become a source of sustainable competitive advantage on a long-term basis.

Grant, (1996) defines an organizational capability as the "ability to perform repeatedly a productive task which relates either directly or indirectly to a firm's capacity for creating value through effecting the transformation of inputs into outputs". Helfat and Peteraf (2003) define organizational capability as 'the ability of an organization to perform a coordinated set of tasks, utilizing organizational resources, for the purpose of achieving a particular end result. Organizational capabilities are fundamental as they provide competitive advantage to firms (Dosi, Nelson \& Winter 2000).

Three types of organizational capabilities: local, architectural and process capabilities were highlighted by Kusunoki et al. (1998). So Internal integration and external integration can be viewed as intra-organizational and inter-organizational core dynamic capabilities of a company (Grant, 1996; Teece et al., 1997). In each dimension of integration we can find local capabilities, architectural capabilities and process capabilities. 


\subsubsection{Intra-organizational Capabilities}

Internal integration can be viewed as a set of Intra-organizational integrative capabilities in which "local capabilities" are related to technology and information system integration within the firm: Enterprise Resource Planning, Advanced Planning and Scheduling System, Integrative inventory management... (Aral \& Weill, 2007), "architectural capabilities" are represented by joint product design, cross-functional teams and connection among all internal functions (Huh, Yook \& Kim, 2008) and "process capabilities" are based on information sharing, collaboration and communication inside organization (Huh et al., 2008; Kusunoki et al., 1998).

\subsubsection{Inter-organizational Capabilities}

External integration (customer integration and internal integration) can be seen as a set of Inter-organizational capabilities in which local capabilities are related to technology and information system integration within supply chain: EDI, quick ordering systems, information networks... (Radhakrishnan, Davis, Sridharan,, Moore \& David, 2017), architectural capabilities and process capabilities refer respectively to joint product design and knowledge and information sharing, collaboration and communication within partners (Gianni \& Andrea, 1999; Lorenzoni \& Lipparini, 1999).

This separation between Intra-organizational capabilities and Inter-organizational capabilities in supply chain integration is also consistent with that of "organizational internal and external core dynamic capabilities" of Huo (2012), and the "internal and external integrative capabilities" of Verona (1999). In Verona's model (1999) as cited by Huo (2012), internal integrative capabilities include internal communication, integrative strategies, job training, process integration; organization reengineering and external integrative capabilities include external communication and networks of collaborations.

\subsection{Impact of SCI on Operational Performance}

In an analysis of the literature review of 25 articles related to the relationship between SCI and performance, Fabbe-Costes and Jahre (2008) showed that, except 2 papers, all authors explicitly agree that the level of integration is positively related to the firm performance. Considered as a set of organizational capabilities, the integration of the supply chain can enable the manufacturer, as a partner, to reduce supply chain disruptions, to adapt to market fluctuations and to meet the requirements of customers in terms of cost, quality and lead time.

\subsubsection{Relationship between SCI Dimensions and Operational Performance of the Manufacturer}

The level of linkage with customers through information networks, the level of computerization for their ordering and the level of communication with them reduce the decision making time. Furthermore, when the manufacturer and their customers share information and strengthen collaborative behavior, they can co-develop product, establish production plans jointly and coordinate the orders fulfillment in order to co-create value for the final consumer.

Customer integration has been found to be positively and significantly related directly to operational performance (Van der Vaart et al., 2007; Flynn et al., 2010; Alfalla-Luque et al., 2013; Wong et al., 2015; Chang, Ellinger, Kim \& Franke, 2016). Furthermore, customer integration impacts indirectly operational performance by improving innovation and product development (Koufteros, Vonderembse \& Jayaram, 2005; Song \& Di Benedetto, 2008). Thus, we hypothesize that:

\section{H1a. Customer integration is positively and significantly related to operational performance of the manufacturer}

Internal integration as intra-organizational capabilities is related to the ability of the manufacturer to integrate process within departments and functions. Instead of a traditional organization based on a fragmented and specialized departments, the internal integration consists of breaking down functional barriers and involves collaboration and information sharing between all departments to meet the requirements of customers. Information sharing, joint planning, periodic contacts and meeting and collaboration in making decisions are a set of important competencies that allow firms to develop a competitive advantage. Moreover, this collaboration needs also some technological competencies of integration of information systems that are related to operational 
performance (Enterprise Resource Planning, Advanced Planning and Scheduling System, Integrative inventory management...).

As it was the case with customer integration, several authors found a positive relationship between internal integration and operational performance (Alfalla-Luque et al., 2013; Flynn et al., 2010; Chang et al., 2016; Van der Vaart et al., 2007; Wong et al., 2015) but other authors found no direct relationship between these two constructs (Koufteros et al., 2005; Giménez \& Ventura, 2005). We can propose thus that:

H1b. Internal integration is positively and significantly related to operational performance of the manufacturer.

In an integrated supply chain, development of a strong strategic partnership with suppliers will facilitate their understanding and anticipation of the manufacturer's needs, in order to better meet its changing requirements (Flynn et al., 2010). As inter-organizational capabilities, sharing information of products, processes, production schedules and plans and collaborate with suppliers helps them to synchronize their own production plans and reduce lead time. By developing a mutual understanding of the manufacturer's operations and process, suppliers achieve a high level of their customer service, which, in turn, helps the manufacturers improve their customer service (Flynn et al., 2010).

Like also customer integration, several authors found a positive relationship between supplier integration and operational performance (Van der Vaart et al., 2007; Flynn et al., 2010; Alfalla-Luque et al., 2013; Wong et al., 2015; Chang et al., 2016), However, others authors have found no relationship (Stank et al., 2001b) or a negative relationship (Koufteros et al., 2005; Stank et al., 2001a; Swink, Narasimhan \& Wang, 2007). We can propose thus:

H1c. Supplier integration is positively and significantly related to operational performance of the manufacturer.

\subsubsection{The Mediating Effect of the Internal Integration}

It is generally accepted in the literature that companies first start by integrating flows and processes internally and then gradually become interested by external integration on their supply chain (Cohen \& Levinthal, 1990; Hillebrand \& Biemans, 2004; Yu et al., 2013).

The relationship between internal integration and external integration can be analyzed according to the different forms of integration capabilities: information sharing, information systems integration, collaboration, coordination, a cross functional team...

In the absence of high internal integration, external integration would be difficult and inefficient. Manufacturers cannot integrate their information system with their partners if their information systems themselves are not integrated (that supposes implementing ERP for example). In addition, companies that have invested well in strengthening the integration of their internal information systems have more opportunity to add modules and interfaces in order to integrate their systems with those of customers and suppliers. Similarly, sharing timely information with customers and suppliers requires sharing information within manufacturers first. Finally, the collaboration with partners supposes that collaborative behavior is already established within the manufacturer (between all departments and functions). Cross functional teams could be, for example, an organizational capacity that the firm can redeploy to resolve conflicts with its external partners and thus enhance collaboration with them.

According to Yu et al. (2013), the level of internal integration is positively and significantly associated with the level of external integration. Alfalla-Luque, Marín-García and Medina-López (2015) have shown that the higher the level of internal integration, the greater the importance of customer integration and supplier integration. In the same way, the more the company develops its internal integration the higher its trust in the interest of the external integration. Carr and Kaynak (2007) have shown that intra-firm information sharing is positively associated with inter-firm information sharing. Similarly, Ward and Zhou (2006) have confirmed the existence of a positive correlation between intra- and inter-organizational integrations of information technologies. So, we suppose that external integration is positively and significantly associated with internal integration and we note:

H2a. There is a positive and significant relationship between internal integration and customer integration.

$\boldsymbol{H} \mathbf{2 b}$. There is a positive and significant relationship between internal integration and supplier integration. 
Furthermore, Kanter (1994) states that internal integration (including information sharing, interdepartmental collaboration, team-work) is important for establishing and maintaining alliances with customers and suppliers. He adds that internal collaboration allows firms to take widely advantage of their alliances and cooperation with their partners.

Stank et al. (2001b) argue that external collaboration contributes directly to logistics performance only when it can improve internal integration. In the same vein, downstream integration can improve logistics performance when the level of internal integration is high. (Germain \& Iyer, 2006).

Finally, Rodrigues, Stank and Lynch (2004) conclude that integrating separately the internal and external business processes doesn't affect significantly the performance of the firm but they have a positive and significant effect when they are combined.

We suppose, at least, that internal integration can mediate the relationship between both of customer integration and supplier integration and the operational performance of manufacturers. Based on this, we can assume that:

H3a. Internal integration has a mediating effect on the relationship between customer integration and operational performance of the manufacturer.

H3b. Internal integration has a mediating effect on the relationship between supplier integration and operational performance of the manufacturer.

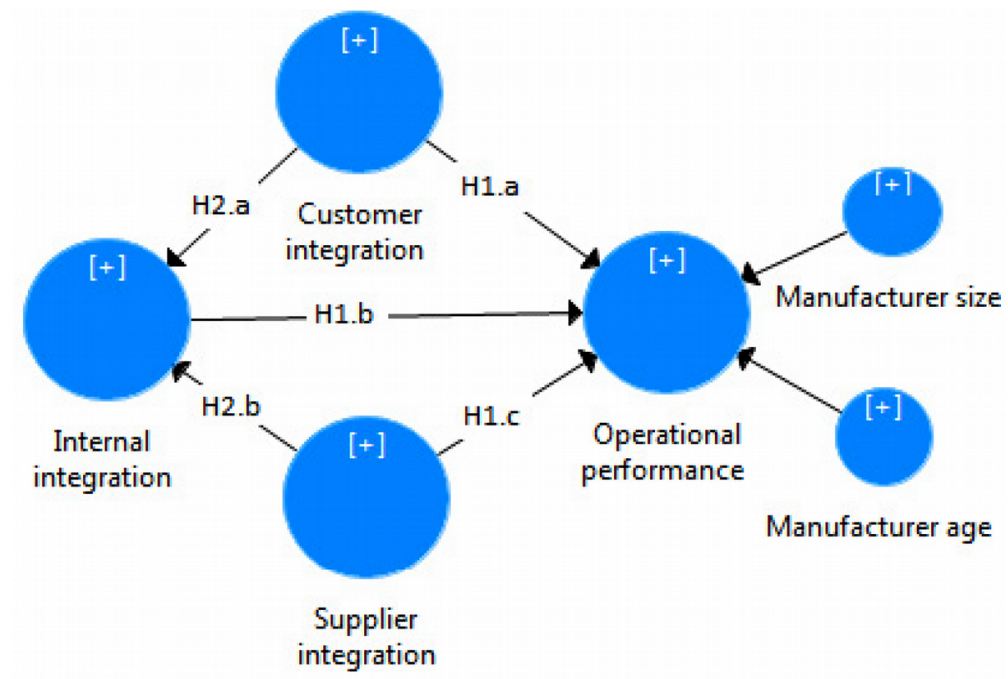

Figure 1. Theoretical model and research hypothesis

\section{Research Methodology}

\subsection{Questionnaire Design and Measures}

We collected data in this research by using a questionnaire. The questionnaire is considered as the most preferred instrument in supply chain management surveys. It is used in almost $42 \%$ of the supply chain integration researches (Irani, 2014). This type of method is usually used to test hypothesis of a theoretical model.

We surveyed the literature to identify valid items and we opted for new measures based on our observations during our exploratory study in order to take on account the specific context of Moroccan manufacturing companies. All constructs were measured using five-point Likert scale. In fact, scales with 5 points are considered more able to decrease confusion and consequently enhance the response rate (Babakus \& Mangold 1992; Devlin, Dong \& Brown, 1993). They are simple to read and allow the respondent to better understand all proposed scales, Dawes (2008).

For operational performance, cost, flexibility and are the basic determinants of performance in operations management literature (Neely, Gregory \& Platts, 1995). Moreover, in the context of the supply chain, firms must 
develop their time-based competition; their performance should also take into account their ability to respond quickly to customer needs and to adapt to demand changes. So we referred to Flynn et al. (2010), Wong et al. (2011), Huo (2012), Liu, Ke, Wei and Zhua (2013) and Liu, Jgjit and Steve (2016) to select items.

For the three constructs of integration, we have selected in the literature review the items that seem adapted to Moroccan manufacturing companies. This construct takes into account items that reflect the level of information integration which focuses on the degree of information systems integration and the level of information sharing. (Droge, Jayaram \& Vickery, 2004; Ellinger, Daugherty \& Keller, 2000; Flynn et al., 2010; Narasimhan \& Kim, 2001; Stank et al., 2001a; Vijayasarathy, 2010; Van der Vaart and van Donk, 2008).

Other items were introduced to take into consideration the collaborative dimension of integration. Some items come from the exploratory study and others are adapted from the literature review (Cai, Jun, \& Yang, 2010; Cao \& Zhang, 2011; Simatupang \& Sridharan, 2002, 2005, 2008; Zacharia, 2009) as cited by Hudnurkar, Jakhar and Rathod (2014). Some of these items was validated through a psychometric testing by Marín-García, Alfalla-Luque and Medina-López, C. (2013).

In the end, we adopted 8 items for operational performance, 10 items for "customer integration", 8 items for "internal integration" and 9 items for "supplier integration". The questionnaire was developed in English then translated into French. (We have translated the exploratory items from French into English). To control for the effect of contextual variables on the impact of supply chain integration, firm age and firm size were considered, which were measured by objective data; age by the number of years past inception, and size by the average total number of employees in the last three years according to Hadid, Mansouri \& Gallear, (2016).

In our research, the questionnaire was double-tested. Firstly, we have submitted it directly to supply chain management professors at the international conferences we attended. In the second test, we submitted the questionnaire to some professionals (plant managers, supply chain managers and logistics managers) whom we met in the Moroccan International Exhibition of Automotive Subcontracting (April 2018). Then, we modified formulations of some questions and added or deleted other questions in order to adapt items to manufacturer's Moroccan context.

\subsection{Sampling and Data Collection}

A sample of 502 Moroccan manufacturing firms was identified using a database compiled by ourselves from the database of the Ministry of Industry and the four professional associations of four industries (automotive, aerospace, electric\& electronic and textile). To be included, a firm should employ more than 50 employees. We limited the sample to medium and large firms because we expect that small firms are less likely to implement supply chain management practices and to four industries because the supply chain of those industries, in Moroccan context, is more complex and the integration is more important and more benefic when the complexity of the supply chain is higher (Van der Vaart et al., 2012; Wong et al., 2015). Supply chain complexity of these companies is higher because of many reasons: They are mainly export-oriented; they are mostly partners in a complex global supply chain; they have a complex technology and production process and they operate in an uncertain environment.

We have opted for a convenience method to administer the questionnaire, but in order to make our sample more representative, we targeted companies in respect for a quota in which we tried to take into account the weight of each sector according to the number of companies. The questionnaires were addressed personally to plant manager, supply chain manager, logistics manager or production/quality manager, since these individuals are expected to have the knowledge needed to accurately respond (Hadid et al., 2016). We have obtained in total 75 questionnaires yielding a response rate of $14,96 \%$. Appendix 2 provides more information on the sample.

\section{Analysis and Hypothesis Testing}

We used Partial least squares structural equation modeling (PLS-SEM) to test the hypothesis of the research model. Like SEM (CB-SEM), PLS-SEM is useful for latent constructs and has two components: measurement (outer) model and structural (inner) model and (Hair, Sarstedt \& Ringl, 2011). PLS-SEM does not require normality of 
data which is necessary for CB-SEM (Hair et al., 2011). In addition, PLS-SEM is capable of estimating models with small sample sizes (Hair et al., 2011) contrary to SEM (CB-SEM) which require large sample size. So, we used PLS-SEM given the size of our sample and because of lack of normality of data. We meet such justifications in some operations management researches (Hadid et al., 2016).

\subsection{Reliability and Validity}

In the process of verifying the validity of the scales of measurement, a factorial analysis with Principal Component Analysis, and Cronbach's alpha as well as the Kaiser-Meyer-Olkin index (KMO) were used to enhance reliability and unidimensionality of constructs. After purging items we adopted 5 items for operational performance, 8 items for "customer integration", 8 items for "internal integration" and also 8 items for "supplier integration. The complete scales are listed in Appendix 1.

Evaluation of the measurement model assumes a confirmatory evaluation of the convergent and discriminant validity (Campbell \& Fiske, 1959) of the constructs as well as an assessment of predictability of the model. To assess the validity and reliability of each construct, we followed the recommendations of Hair et al. (2011). We examined the Cronbach's Alpha $(>0,7)$, the rho_A $(>0,7)$, the composite reliability $(>0,7)$, and average variance extracted (AVE $>0,5)$. The Table 1 shows that all of these criteria exceed the required thresholds.

\begin{tabular}{|l|r|r|r|r|}
\hline & Cronbach's Alpha & \multicolumn{1}{|c|}{ rho_A } & $\begin{array}{c}\text { Composite } \\
\text { Reliability }\end{array}$ & $\begin{array}{c}\text { Average Variance } \\
\text { Extracted (AVE) }\end{array}$ \\
\hline Customer integration & 0.922 & 0.932 & 0.942 & 0.672 \\
\hline Internal integration & 0.932 & 0.942 & 0.945 & 0.683 \\
\hline Supplier integration & 0.929 & 0.936 & 0.942 & 0.669 \\
\hline Operational performance & 0.890 & 0.904 & 0.920 & 0.700 \\
\hline
\end{tabular}

Table 1 . Construct validity and reliability

\begin{tabular}{|l|r|r|r|r|r|r|}
\hline & $\begin{array}{c}\text { Customer } \\
\text { integration }\end{array}$ & $\begin{array}{c}\text { Internal } \\
\text { integration }\end{array}$ & \multicolumn{1}{c|}{ Age } & Size & $\begin{array}{c}\text { Operational } \\
\text { performance }\end{array}$ & $\begin{array}{c}\text { Supplier } \\
\text { integration }\end{array}$ \\
\hline Customer integration & $\mathbf{0 . 8 1 9 *}$ & & & & & \\
\hline Internal integration & 0.785 & $\mathbf{0 . 8 2 6}$ & & & & \\
\hline Manufacturer age & 0.168 & 0.179 & $\mathbf{1 . 0 0 0}$ & & & \\
\hline Manufacturer size & 0.248 & 0.226 & 0.321 & $\mathbf{1 . 0 0 0}$ & & \\
\hline Operational performance & 0.800 & 0.791 & 0.090 & 0.159 & $\mathbf{0 . 8 3 7}$ & \\
\hline Supplier integration & 0.788 & 0.773 & 0.126 & 0.176 & 0.782 & $\mathbf{0 . 8 1 8}$ \\
\hline
\end{tabular}

* Values in the diagonal represent the square root of AVE for each construct.

Table 2. Discriminant validity: Fornell-Larcker Criterion (Smartpls outputs)

\begin{tabular}{|l|r|r|r|r|r|}
\hline & $\begin{array}{c}\text { Customer } \\
\text { integration }\end{array}$ & $\begin{array}{c}\text { Internal } \\
\text { integration }\end{array}$ & $\begin{array}{c}\text { Manufacturer } \\
\text { age }\end{array}$ & $\begin{array}{c}\text { Manufacturer } \\
\text { size }\end{array}$ & $\begin{array}{c}\text { Operational } \\
\text { performance }\end{array}$ \\
\hline Internal integration & 0.832 & & & & \\
\hline Manufacturer age & 0.176 & 0.182 & & & \\
\hline Manufacturer size & 0.255 & 0.242 & 0.321 & & \\
\hline Operational performance & 0.871 & 0.867 & 0.105 & 0.175 & \\
\hline Supplier integration & 0.841 & 0.822 & 0.129 & 0.192 & 0.849 \\
\hline
\end{tabular}

Table 3. Discriminant validity: Henseler Criterion (Smartpls outputs) 
Then we assessed discriminant validity through Fornell-Larcker criterion (Discriminant validity is evident if the square root of AVE of a construct is greater than its correlations with other constructs in the model (Fornell \& Larcker, 1981) and Heterotrait-Monotrait ratio (HTMT), Henseler et al. (2015) suggest a threshold value of 0.90. Tables 2 and 3 support discriminant validity of our model.

\subsection{Model's Fit and Predictive Capabilities}

After confirming that the construct measures are reliable and valid, we will evaluate in the next step the assessment of the structural model results. These needs examining the model's predictive capabilities and the model's fit.

Before, we examined the structural model for collinearity through "VIF value". VIF above 5 in the predictor constructs is a critical level of collinearity between construct (Hair et al., 2011). Table 4 shows that all VIF values are below 5 .

Then, $\mathrm{R}^{2}$ and path coefficients $(\beta)$ along with their significance were used for model assessment criteria (Hair et al., 2011). We used "bootstrapping" as resampling techniques to evaluate path coefficients and t-statistics (Lee, Petter, Fayard \& Robinson, 2011). Hair et al. (2011) pointed out that the larger the number of samples used during the bootstrapping process, the more robust the findings will be. Thus, the bootstrapping process was applied on 1000 samples following the recommendations of Hair et al. (2011). $\mathrm{R}^{2}$ values in the model are equal respectively to 0,674 and 0,749 and they are described as substantial according to Hair et al. (2011) and Henseler, Ringle and Sinkovics (2009).

In addition, we used $f^{2}$ effect size to evaluate the change in the $\mathrm{R}^{2}$ value when a specified exogenous construct is omitted from the model. $f^{2}$ values in our model are medium according to Cohen (1988). Effect size values of less than 0.02 indicate that there is no effect.

We evaluated the predictive capability of the model by the Stone-Geisser Q2 value (Geisser, 1974; Stone, 1974) by using the blindfolding technique (Hair et al., 2011). When Q2 value is larger than zero, the exogenous constructs have predictive relevance for the endogenous constructs included in the model Geisser, 1974; Stone, 1974). Table 5 shows that Q2' values of model are all above 0 .

\begin{tabular}{|l|r|r|}
\hline & \multicolumn{1}{|c|}{$\begin{array}{c}\text { Internal } \\
\text { integration }\end{array}$} & $\begin{array}{c}\text { Operational } \\
\text { performance }\end{array}$ \\
\hline Customer integration & 2.637 & 3.363 \\
\hline Internal integration & & 3.144 \\
\hline Supplier integration & 2.637 & 3.169 \\
\hline
\end{tabular}

Table 4. Collinearity Statistics (VIF)

\begin{tabular}{|l|l|r|r|}
\hline \multicolumn{2}{|c|}{} & \multicolumn{1}{c|}{$\begin{array}{c}\text { Internal } \\
\text { integration }\end{array}$} & $\begin{array}{c}\text { Operational } \\
\text { performance }\end{array}$ \\
\hline $\mathrm{R}^{2}$ & 0.679 & 0.737 \\
\hline \multirow{2}{*}{$f^{2}$} & Customer integration & 0.253 & 0.141 \\
\cline { 2 - 4 } & Internal integration & & 0.130 \\
\cline { 2 - 4 } & Supplier integration & 0.197 & 0.083 \\
\hline $\mathrm{Q}^{2}$ & & 0.416 & 0.464 \\
\hline
\end{tabular}

Table 5. Assessment and predictive criteria values (Smartpls blindfolding' output)

Finally, we used the standardized root mean square residual (SRMR), as a criterion model fit measure known from CB-SEM. More recently, Henseler et al., 2014 assessed the efficacy of SRMR as a model fit measure (Hair, Hult, Ringle \& Sarstedt, 2017) the feature is available in Smartpls. The SRMR is defined as the root mean square discrepancy between the observed correlations and the model-implied correlations. Because the SRMR is an absolute measure of fit, a value of zero indicates perfect fit (Hu \& Bentler, 1999). In CB-SEM algorithm, An 
SRMR value that is less than 0.08 is generally considered a good fit (Hu \& Bentler, 1999). Even this threshold is likely too low for PLS-SEM (Hair et al., 2011), in our model, SRMR is equal to $\mathbf{0 , 0 7 7}$ which could be judged as acceptable fit.

\subsection{Hypothesis Testing}

We tested the hypotheses in two blocks. The first examined the direct effect of the three dimensions of integration on firm performance (H1a, H1b and H1c). The second highlighted the mediating effect of internal integration (H3a, H3b) which is supposed to test firstly, relationships between internal integration and both of supplier and customer integration (H2a, H2b). Figure 2 summarizes all path coefficient of structural model.

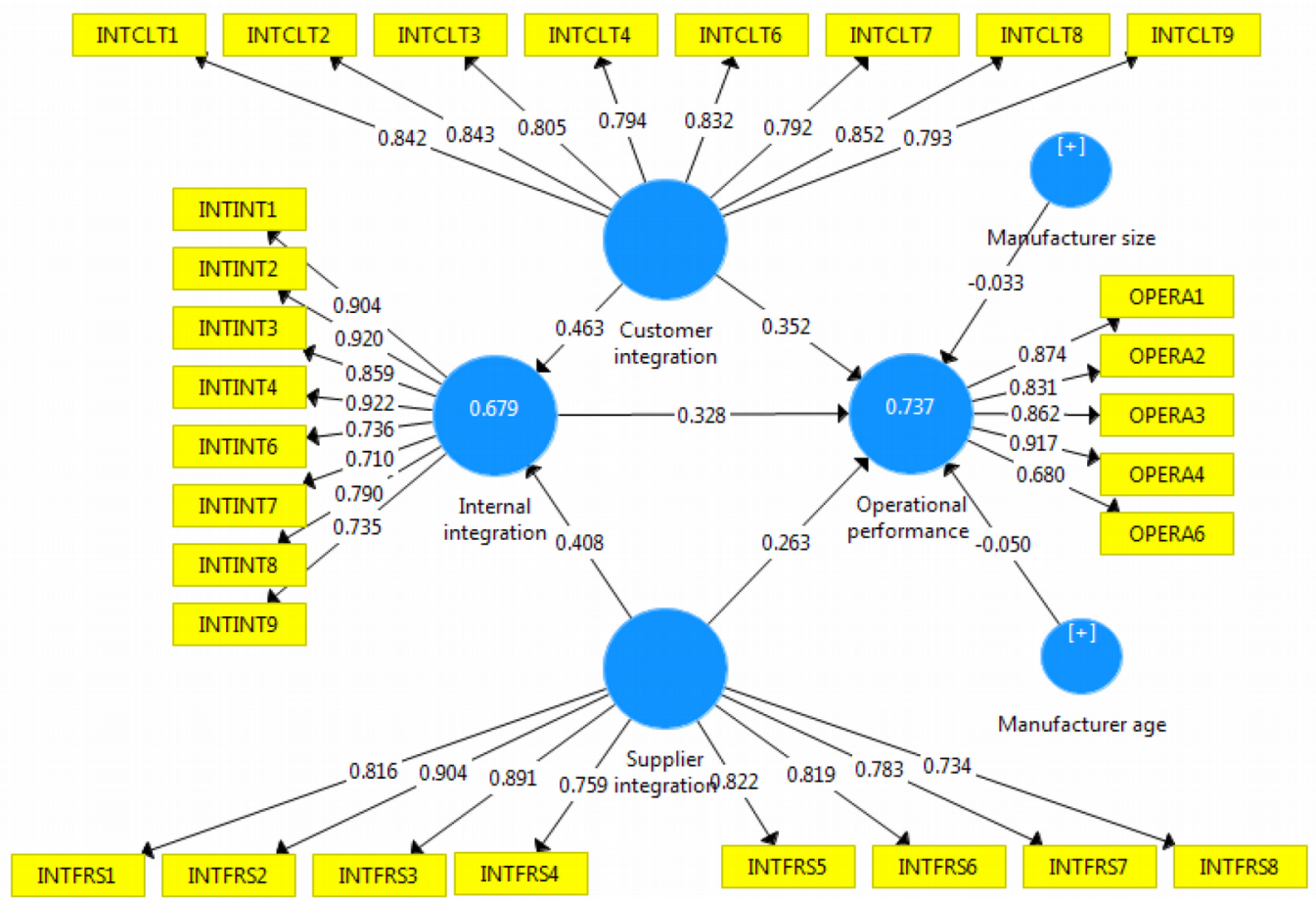

Figure 2. Path coefficient of structural model (Smartpls outputs)

\subsubsection{Direct effect}

The Smartpls bootstrapping process results show that internal integration and customer integration are both positively and significantly associated with operational performance of the manufacturers at $\mathrm{p}>0.01$ and supplier integration is positively and significantly associated with operational performance at $\mathrm{p}>0.05$. Thus, H1a, H1b and H1c are all supported. Related to the path coefficients, the effect of customer integration (0.352) is higher than both of internal integration (0.328) and supplier integration effect (0.263). 


\begin{tabular}{|l|r|r|r|r|r|}
\hline & $\begin{array}{c}\text { Original } \\
\text { Sample (O) }\end{array}$ & $\begin{array}{c}\text { Sample } \\
\text { Mean (M) }\end{array}$ & $\begin{array}{c}\text { Standard } \\
\text { Deviation } \\
\text { (STDEV) }\end{array}$ & T Statistics & P Values \\
\hline Customer integration -> Internal integration & $\mathbf{0 . 4 6 3}$ & 0.468 & 0.129 & 3.737 & $\mathbf{0 . 0 0 0 * * *}$ \\
\hline Customer integration -> Operational performance & $\mathbf{0 . 3 5 2}$ & 0.339 & 0.105 & 3.353 & $\mathbf{0 . 0 0 1 * *}$ \\
\hline Internal integration -> Operational performance & $\mathbf{0 . 3 2 8}$ & 0.342 & 0.146 & 2.249 & $\mathbf{0 . 0 2 5 *}$ \\
\hline Manufacturer age -> Operational performance & $\mathbf{- 0 . 0 5 0}$ & -0.046 & 0.064 & 0.779 & $\mathbf{0 . 4 3 6}$ \\
\hline Manufacturer size -> Operational performance & $\mathbf{- 0 . 0 3 3}$ & -0.031 & 0.065 & 0.504 & $\mathbf{0 . 6 1 4}$ \\
\hline Supplier integration -> Internal integration & $\mathbf{0 . 4 0 8}$ & 0.406 & 0.150 & 2.811 & $\mathbf{0 . 0 0 5 * *}$ \\
\hline Supplier integration -> Operational performance & $\mathbf{0 . 2 6 3}$ & 0.268 & 0.126 & 2.087 & $\mathbf{0 . 0 3 7 *}$ \\
\hline
\end{tabular}

${ }^{*} \mathrm{p} \leq 0.05,{ }^{* *} \mathrm{p} \leq 0.01,{ }^{* * *} \mathrm{p} \leq 0.001$

Table 6. Direct effect (Smartpls outputs)

\subsubsection{Mediating Effect}

Mediation occurs when a third mediator variable intervenes between two other related constructs. Testing for the type of mediation in a model requires running a series of analyses. The first step addresses the significance of the indirect effect via the mediator variable. If the indirect effect is not significant we conclude that there is no mediating effect (Hair et al., 2017).

The mediating effect of internal integration supposes firstly a positive and significant relationship with both of customer and supplier integration. Table 5 confirms that internal integration is positively and significantly associated with customer integration and supplier integration (at $\mathrm{p}>0.01$ ). Consequently, $\mathrm{H} 2 a$ and $\mathrm{H} 2 \mathrm{~b}$ are all supported.

Then, we followed the testing procedures of Preacher and Hayes (2008) to test the hypothesis of the mediating effect. According to these authors the mediating effect supposes that the indirect effect must be significant and the confidence interval must not contain zero.

We used Smartpls bootstrapping to calculate the specific indirect effects. Table 6 shows that only specific indirect effects of customer integration is significant confidence intervals does not contain zero. The specific indirect effect of customer integration is significant at $\mathrm{p}>0.05$ and specific indirect effect of supplier integration is not significant. Thus, internal integration mediates relationship between customer integration and operational performance and supplier integration and operational performance. Thus, H3a is supported and H3b is not supported.

\begin{tabular}{|l|r|r|r|r|r|r|r|}
\hline & $\begin{array}{c}\text { Original } \\
\text { Sample (O) }\end{array}$ & $\begin{array}{c}\text { Sample } \\
\text { Mean (M) }\end{array}$ & $\begin{array}{c}\text { Standard } \\
\text { Deviation } \\
\text { (STDEV) }\end{array}$ & $\begin{array}{c}\text { T } \\
\text { Statistics }\end{array}$ & P Values & \multicolumn{2}{|c|}{ Confidence interval } \\
\cline { 1 - 7 } $\begin{array}{l}\text { Customer integration -> } \\
\text { Internal integration -> } \\
\text { Operational performance }\end{array}$ & 0.169 & 0.167 & 0.075 & 2.255 & $0.025^{*}$ & $\mathbf{0 . 0 3 9}$ & $\mathbf{0 . 3 3 3}$ \\
\hline $\begin{array}{l}\text { Supplier integration -> } \\
\text { Internal integration -> } \\
\text { Operational performance }\end{array}$ & 0.149 & 0.145 & 0.085 & 1.763 & $0.078^{*}$ & $\mathbf{0 . 0 1 3}$ & $\mathbf{0 . 3 3 4}$ \\
\hline
\end{tabular}

${ }^{*} \mathrm{p} \leq 0.05$;

Table 7. Specific Indirect Effects and Confidence interval

\section{Discussion and Implications of Results}

In the Moroccan context, manufacturing companies need more supply chain integration in order to enhance their operational performance because of the complexity of supply chain. These companies are partners of a world 
global supply chain which aspires to be more and more integrated. In addition, supply chain integration practices and behaviors are considered as a source of competitive advantage. The results of this study confirm the positive effect of the level of all dimensions of integration on operational performance in these companies which corroborates numerous findings reached by the researchers who worked on supply chain integration (Van der Vaart et al., 2007; Flynn et al., 2010; Alfalla-Luque et al., 2013; Wong et al. 2015; Chang et al., 2016).

The results confirm our assumptions that sharing information and collaborating with their major customers and suppliers in the business process can enhance firms' operational performance. The collaboration in the supply chain allows firms to understand the needs of their customers and to respond exactly to these needs. Likewise, partners who establish jointly demand forecasts and production schedules can minimize supply chain disruptions and quickly respond to changes in market demand. This is considered as a competitive advantage for the manufacturer given the high environment's uncertainty of automotive, aerospace, electronics and textile industries: product change and innovation, material and information flows complexity (Just-in-time) and business process complexity.

Moreover, the position of these companies in the global supply chain, insofar as they are mostly subcontractors, involves more downstream integration and consequently more internal integration. This is the reason why customer integration has a high effect on operational performance. Although supplier integration has a significant effect, its size effect is still small ( $\mathrm{f}=0.083$ ) according to Cohen (1988) comparatively with customer integration and internal integration which have a medium effect ( $\mathrm{f}$ value are respectively $0-.141$ and 0.130 ). We therefore assume that their integration is also the result of upstream integration's efforts undertaken by the customers themselves. Thus, the supply chain integration is seen as a customer's constraint which involves more internal integration from the manufacturer. This internal integration helps manufacturers to increase supplier integration. The empirical results of our research confirmed the positive and significant association between external integration and internal integration of Moroccan companies which corroborates findings by previous researches (Yu et al., 2013, AlfallaLuque, et al., 2015).

Finally, we refer to Zhao, Lynch and Chen (2010), who offer a synthesis of prior research on mediation analysis, to explain the nature of mediation in our research. The authors identified three types of mediation: Complementary mediation: The indirect effect and the direct effect both are significant and point in the same direction; Competitive mediation: The indirect effect and the direct effect both are significant and point in opposite directions and full mediation: The indirect effect is significant but not the direct effect. The results show that both the direct effect and the indirect effect of customer integration on operational performance are significant (the product of the tow effect is positive). The mediation of internal integration is therefore complementary and partial.

According to Hair et al. (2017), while providing support for the hypothesized mediating relationship, complementary mediation also provides a cue that another mediator may have been omitted indirect path of which has the same direction as the direct effect. We suppose then that the relationship between external integration and operational performance may be mediated by other factors in the case of manufacturing companies like quality and duration of the relationship between supply chain partners (Prajogo \& Olhager, 2012; Chang et al., 2016) national culture (Chang et al., 2016) and top management support (Zhao et al., 2015).

\section{Conclusion}

Our study set out to understand how supply chain integration impacts operational performance of manufacturing firms and how internal integration mediates relationship between external integration and operational performance in the Moroccan context. To do so, supply chain integration was viewed as a set of intra-organizational and inter-organizational capabilities. The internal side of integration was considered as intra-organizational capabilities and the external one was considered as inter-organizational capabilities.

We used data from 75 Moroccan manufacturing firms in automotive, aerospace, electronics and textile industries and we used Smartpls software to analyze data. It was found that all dimensions of the integration impact positively and significantly the operational performance of these companies and that internal integration mediates only the relationship between customer integration and operational performance. 
These findings contribute to the current supply chain integration literature by extending the empirical results to the Moroccan context and adopting an improved theoretical framework. As suggested by Fabbe-Costes and Jahre (2008) "it is important to return to the theoretical bases "behind" prevailing research. Having an integrated approach also implies being critical and reflective. Strengthening theoretical bases will enhance accuracy in defining concepts and relationships between concepts".

Like most studies, this study has also some limitations. First of all, the supply chain in our research is considered as a network including customers, manufacturers and suppliers. However, Carter et al (2015) suggest that supply chain must be conceptualized as a network that includes also a support supply chain which means other partners through which a product does not flow, but support the physical supply chain of that product (financial institutions, brokers, and truckload transportation).

Another limitation arises from using subjective measures for measuring operational performance despite the fact that these subjective measures have and continue to be widely used in operations management literature (Gruber, Heinemann, Brettel \& Hungeling, 2010; Rai \& Tang, 2010). Likewise, we collected data from plant and senior level managers who were expected to be able to have correct information about the variables of the research (Rai, Patnayakuni \& Seth, 2006). Despite that this method largely used in the literature of supply chain management and has widely been adopted by similar studies, there is some authors suggesting that senior managers may not always have all information on the practices used in their organizations (Leyer \& Moormann, 2014). Furthermore, the sample size in our research is relatively small and the effect of its size is also a limitation of this study. Our sample includes only firms of automotive, aerospace electronic and textile industries therefore the results may not be applicable to other manufacturing firms.

Consequently, further researches may take into account the new theory building of supply chain in order to improve the theoretical framework of supply chain integration and its impact on firm performance. Moreover, since other factors which can mediate relationship between external integration and operational performance exist as we suggested, new further researches are encouraged to integrate other variables as mediating effects. Finally, employing larger samples and relying on multiple-item measures from more than one participant per firm may enhance possibilities of results generalization.

\section{Declaration of Conflicting Interests}

The authors declared no potential conflicts of interest with respect to the research, authorship, and/or publication of this article.

\section{Funding}

The authors received no financial support for the research, authorship, and/or publication of this article.

\section{References}

Alfalla-Luque, R., Marín-García, J., \& Medina-Lopez, C. (2015). An analysis of the direct and mediated effects of employee commitment and supply chain integration on organizational performance. International Journal of Production Economics, 162, 242-257. https://doi.org/10.1016/j.ijpe.2014.07.004

Alfalla-Luque, R., López, C.M., \& Dey, P.K. (2013). Supply chain integration framework using literature review. Production Planning \& Control, 8-9, 800-817. https://doi.org/10.1080/09537287.2012.666870

Aral, S., \& Weill, P. (2007). IT assets, organizational capabilities, and firm performance: how resource allocations and organizational differences explain performance variation. Organization Science, 18(5), 763-80. https://doi.org/10.1287/orsc.1070.0306

Babacus, E., \& Mangold, W.G. (1992). Adapting the SERVQUAL scale to hospital services: An empirical investigation. Health Ser Res, 26(2), 767-786. https://doi.org/PMC1069855

Barratt, M., \& Barratt, R. (2011). Exploring internal and external supply chain linkages: Evidence from the field. Journal of Operations Management, 29(5), 514-528. https://doi.org/10.1016/j.jom.2010.11.006 
Cai, S., Jun, M., \& Yang, Z. (2010). Implementing supply chain information integration in China: The role of institutional forces and trust. Journal of Operations Management, 28(3), 257-268.

https://doi.org/10.1016/j.jom.2009.11.005

Campbell, D., \& Fiske, D.W. (1959). Convergent and discriminant validation by the multitrait-multimethod matrix. Psychological Bulletin, 54, 297-312. http:/ /dx.doi.org/10.1037/h0046016

Cao, M., \& Zhang, Q. (2011). Supply chain collaboration: Impact on collaborative advantage and firm performance. Journal of Operations Management, 29(3), 163-180. https://doi.org/10.1016/j.jom.2010.12.008

Carter, C.R., Rogers, D.S., \& Choi, T.Y. (2015). Toward the Theory of the Supply Chain. J Supply Chain Management, 51, 89-97 https://doi.org/10.1016/j.jom.2010.12.008

Carr, A.S., \& Kaynak, H. (2007). Communication Methods, Information Sharing, Supplier Development and Performance: An Empirical Study of Their Relationships. International Journal of Operations \& Production Management, 27(4), 346-370. https:// doi.org/10.1108/01443570710736958

Chang, W., Ellinger, A.E., Kim, K., \& Franke, G.R (2016). Supply chain integration and firm financial performance: A meta-analysis of positional advantage mediation and moderating factors. European Management Journal, 34(3-6), 282-229. https://doi.org/10.1016/j.emj.2015.11.008

Cohen, J. (1988). Statistical power analysis for the behavioral sciences (2nd ed.). Hillsdale, NJ: Lawrence Earlbaum Associates.

Cohen, W.M., \& Levinthal, D.A. (1990). Absorptive Capacity: A New Perspective on Learning and Innovation. Administrative Science Quarterly, 35, 128-152. https://www.jstor.org/stable/2393553

Comelli, M., Fenies, P., \& Tchernev, N. (2007). A combined financial and physical flows evaluation for logistic process and tactical production planning: Application in a company supply chain. International Journal of Production Economics, 112(1), 77-95. https://doi.org/10.1016/j.ijpe.2007.01.012

Cousins, P.D., \& Menguc, B. (2006). The implications of socialization and integration in supply chain management. Journal of Operations Management, 604-620. https:/ / doi.org/10.1016/j.jom.2005.09.001

Dawes, J.G. (2008). Do data characteristics change according to the number of scale points used? An experiment using 5 point, 7 point and 10 point scales. International journal of market research, 51(1). https://ssrn.com/abstract $=2013613$

Devlin, S.J., Dong, H.K., \& Brown, M. (1993). Selecting A Scale for Measuring Quality. Marketing Research: A Magazine of Management and Applications, 5, 12-17.

Dong, Y., Carter, C.R., \& Dresner, M.E. (2001). JIT purchasing and performance: an exploratory analysis of buyer and supplier perspectives. Journal of Operations Management, 19(4): 471-483. https://doi.org/10.1016/S02726963(00)00066-8

Dosi, G., Nelson, R.R., \& Winter, S.G. (2000). Introduction: The Nature and Dynamics of Organisational Capabilities'. In Dosi, G., Nelson, R.R., \& Winter, S.G. (Eds.), The Nature and Dynamics of Organisational Capabilities (1-22). Oxford: Oxford University Press.

Droge, C., Jayaram, J., \& Vickery, S.K. (2004). The effects of internal versus external integration practices on time-based performance and over all firm performance. Journal of Operations Management, 22, 557-573. https://doi.org/10.1016/j.jom.2004.08.001

Ellinger, A.E., Daugherty, P.J., \& Keller, S.B. (2000). The relationship between marketing/logistics interdepartmental integration and performance in US manufacturing firm. Journal of Business Logistics, 21(1), 1-22.

Fabbe-Costes, N., \& Jahre, M. (2008). Supply chain integration and performance: a review of the evidence. The International Journal of Logistics Management, 19(2), 130-154. https:/ / doi.org/10.1108/09574090810895933

Flynn, B.B., Huob, B., \& Zhaod, X. (2010). The impact of supply chain integration on performance: A contingency and configuration approach. Journal of Operations Management, 28(1), January, 58-71.

https://doi.org/10.1016/j.jom.2009.06.001 
Fornell, C., \& Larcker, D.F. (1981). Evaluating structural equation models with unobservable variables and measurement error. Journal of Marketing Research, 18(1), 39-50. https://doi.org/10.2307/3151312

Frohlich, M.T., \& Westbrook, R. (2001). Arcs of integration: an international study of supply chain strategies. Journal of Operations Management, 19(2), 185-200. https://doi.org/10.1016/s0272-6963(00)00055-3

Geisser, S. (1974). A Predictive Approach to the Random Effects Model. Biometrika, 61(1), 101-107.

Germain, R., \& Iyer, K. (2006). The interaction of internal and downstream integration and its association with performance. Journal of Business Logistics, 27(2), 29-52. https:/ /doi.org/10.1002/j.2158-1592.2006.tb00216.x

Gianni, L., \& Andrea, L. (1999). The leveraging of inter-firm relationships as a distinctive organizational capability: a longitudinal study. Strategic Management Journal, 20(4), 317-38. https://www.jstor.org/stable/3094214

Giménez, C., \& Ventura, E. (2005). Logistics-production, logistics-marketing and external integration: Their impact on performance. International Journal of Operations \& Production Management, 25(1), 20-38. https://doi.org/10.1108/01443570510572222

Grant, R.M. (1996). Prospering in dynamically-competitive environments: organizational capability as knowledge integration. Organization Science, 7(4), 375-87. https://www.jstor.org/stable/2635098

Greis, N.P., \& Kasarda, J.D. (1997). Enterprise Logistics in the Information Era. California Management Review, 39(3), 55-78. https://doi.org/10.2307/41165910

Gruber, M., Heinemann, F., Brettel, M., \& Hungeling, S. (2010). Configurations of Resources and Capabilities and Their Performance Implications: An Exploratory Study on Technology Ventures. Strategic Management Journal, 31, 1337-1356. https://doi.org/10.1002/smj.865

Hadid, W., Mansouri, S.A., \& Gallear, D. (2016). Is lean service promising? A socio-technical perspective. International Journal of Operations \& Production Management, 36(6), 618-642. https://doi.org/10.1108/ijopm-01-2015-0008

Hair, J.F., Hult, G.T.M., Ringle, C.M., \& Sarstedt, M. (2017). A Primer on Partial Least Squares Structural Equation Modeling (PLS-SEM) (2nd ed.). Sage: Thousand Oaks.

Hair, J.F., Sarstedt, M., \& Ringle, C.M. (2011). An assessment of the use of partial least squares structural equation modeling in marketing research. Journal of the Academy of Marketing Science, 40 (3), 414-433. https://doi.org/10.1007/s11747-011-0261-6

Helfat, C., \& Peteraf, M. (2003). The dynamic resource based view: Capability lifecycles. Strategic Management Journal, 24(10 SPEC ISS.), 997-1010. https://doi.org/10.1002/smj.332

Henseler, J., Ringle, C.M., \& Sinkovics, R.R. (2009). The use of partial least squares path modeling in international marketing. Advances in International Marketing, 20, 277-319. https://doi.org/10.1108/S1474-7979

Hillebrand, B., \& Biemans, W.G. (2004). Links between Internal and External Cooperation in Product Development: An Exploratory Study. Journal of Product Innovation Management, 21, 110-122. https://doi.org/10.1111/j.0737-6782.2004.00061.x

Hu, L.T., \& Bentler, P.M. (1999). Cutoff Criteria for Fit Indexes in Covariance Structure Analysis: Conventional Criteria versus New Alternatives. Structural Equation Modeling, 6(1), 1-55. https://doi.org/10.1080/10705519909540118

Hudnurkar, M., Jakhar, S., \& Rathod, U. (2014). Factors Affecting Collaboration in Supply Chain: A Literature Review. Procedia - Social and Behavioral Sciences, 133, 189-202. https://doi.org/10.1016/j.sbspro.2014.04.184

Huh, S., Yook, K., \& Kim, I. (2008). Relationship between organizational capabilities and performance of target costing: an empirical study of Japanese companies. Journal of International Business Research, 7(1), 91-107.

Huo, B. (2012). The impact of supply chain integration on company performance: an organizational capability perspective. Supply Chain Management: An International Journal, 17(6), 596-610 https://doi.org/10.1108/13598541211269210 
Huo, B., Qi, Y., Wang, Z., \& Zhao, X. (2014). The impact of supply chain integration on firm performance: The moderating role of competitive strategy. Supply Chain Management: An International Journal, 19(4), 369-384. https://doi.org/10.1108/SCM-03-2013-0096

Huo, B., Zhang, C., \& Zhao, X. (2015). The effect of IT and relationship commitment on supply chain coordination: A contingency and configuration approach. Information \& Management, 52(6), September, 728-740. https://doi.org/10.1016/j.im.2015.06.007

Irani, Z. (2014). Analysing supply chain integration through a systematic literature review: a normative perspective. Supply Chain Management: An International Journal, 19(5/6), 523-557. https://doi.org/10.1108/SCM-12-2013-0491

Kannan, V.R., \& Tan, K.C. (2005). Just in time, total quality management, and supply chain management: understanding their linkages and impact on business performance. Omega, 33, 153-162. https://doi.org/10.1016/j.omega.2004.03.012

Kanter, R.M. (1994). Collaborative Advantage: The Art of Alliances. Harvard Business Review, 72(4), 96.

Koufteros, X., Vonderembse, M., \& Jayaram, J. (2005). Internal and external integration for product development: the contingency effects of uncertainty, equivocality, and platform strategy. Decision Sciences, 36(1), 97-133. https://doi.org/10.1111/j.1540-5915.2005.00067.x

Kusunoki, K., Nonaka, I., \& Nagata, A. (1998). Organizational capabilities in product development of Japanese firms: a conceptual framework and empirical findings. Organization Science, 9(6), 699-718. https://www.jstor.org/stable/2640250

Lee, L., Petter, S., Fayard, D., \& Robinson, S. (2011). On the use of partial least squares path modeling in accounting research. International Journal of Accounting Information Systems, 12 (4), 305-328. https://doi.org/10.1016/j.accinf.2011.05.002

Leyer, M., \& Moormann, J. (2014). How lean are financial service companies really? Empirical evidence from a large scale study in Germany. International Journal of Operations and Production Management, 34 (11), 1366-1388. https://doi.org/10.1108/IJOPM-06-2013-0296

Liu H., Ke, W., Wei, K.K., \& Zhua, Z. (2013). Effects of supply chain integration and market orientation on firm performance: Evidence from China. International Journal of Operations \& Production Management, 33(3), 322-346. https://doi.org/10.1108/01443571311300809

Liu, Y., Luo, Y.D., \& Liu, T. (2009). Governing buyer-supplier relationships through transactional and relational mechanisms: Evidence from China. Journal of Operations Management, 27, 294-309. https://doi.org/10.1016/j.jom.2008.09.004

Liu Y., Jagjit, S.S., \& Steve E. (2016). Environmental management: the role of supply chain capabilities in the auto sector. Supply Chain Management: An International Journal, 21(1), 1-19 (b). https://doi.org/10.1108/SCM-01-2015-0026

Lorenzoni, G., \& Lipparini, A. (1999). The Leveraging of Interfirm Relationships as a Distinctive Organizational Capability: A Longitudinal Study. Strategic Management Journal, 20(4), 317-338. https://www.jstor.org/stable/3094214

Marín-García, J.A., Alfalla-Luque, R., \& Medina-López, C. (2013). Supply chain integration scales validation and benchmark values. Journal of Industrial Engineering and Management, 6(2), 423-440.

Mentzer, J.T., Foggin, J.H., \& Golicic, S.L. (2000). Collaboration: The enablers, impediments, and benefits. Supply Chain Management Review, 4(4), 52-57.

Narasimhan, R., \& Kim, S.W. (2001). Information system utilization strategy for supply chain integration. Journal of Business Logistics, 22, 51-57. https:/ /doi.org/10.1002/j.2158-1592.2001.tb00003.x

Neely, A.D., Gregory, M.J., \& Platts, K.W. (1995). Performance measurement system design: a literature review and research agenda. International Journal of Operations \& Production, 15(4), 80-116.

https://doi.org/10.1108/01443579510083622 
Prajogoa, D., \& Olhager, J., (2012). Supply chain integration and performance: The effects of long-term relationships, information technology and sharing, and logistics integration. International Journal of Production Economics, Elsevier, 135(1), 514-522. https://doi.org/10.1016/j.ijpe.2011.09.001

Preacher, K.J., \& Hayes, A.F. (2008). Asymptotic and resampling strategies for assessing and comparing indirect effects in simple and multiple mediation models. Behavior Research Methods, 40, 879-891.

https://doi.org/10.3758/BRM.40.3.879

Radhakrishnan, A., Davis, J., Sridharan, S.V., Moore, D., \& David, D. (2018). The impact of inter organizational information systems-enabled external integration on capabilities of buyer supplier dyads. Journal European Management Journal, 36(4), 558-572. https://doi.org/10.1016/j.emj.2017.09.006

Rai, A., \& Tang, X. (2010). Leveraging IT capabilities and competitive process capabilities for the management of interorganizational relationship portfolios. Inf Syst Res, 21(3), 516-542. https://www.jstor.org/stable/25148729

Rai, A., Patnayakuni, R., \& Seth, N., (2006). Firm performance impacts of digitally enabled supply chain integration capabilities. MIS Q, 30(2), 225-246. https://www.jstor.org/stable/25148729

Rodrigues, A., Stank, T., \& Lynch, D. (2004). Linking strategy, structure, process, and performance in integrated logistics. Journal of Business Logistics, 25(2), 65-94. https://doi.org/10.1002/j.2158-1592.2004.tb00182.x

Ryan, D., Emond, M., \& La Montagne, M.E. (2014). Social Network Analysis as a Metric for the Development of an Interdisciplinary, Inter-Organizational Research Team”. Journal of Inter-professional Care, 28(1), $28-33$. https://doi.org/10.3109/13561820.2013.823385

Saeed, K.A., Malhotra, M.K., \& Grover, V. (2005). Examining the impact of inter-organizational systems on process efficiency and sourcing leverage in buyer supplier dyads. Decision Sciences, 36(3), 365-396.

Sahin, F., \& Robinson Jr., E.P. (2005). Information sharing and coordination in make -to-order supply chains. Journal of Operations Management, 23(6), 579-598. https://doi.org/2013.12.194

Simatupang, T.M., \& Sridharan, R. (2008). Design for supply chain Collaboration. Business Process Management Journal, 14(3), 401-418. https://doi.org/10.1108/14637150810876698

Simatupang, T.M., \& Sridharan R. (2005). The collaboration index: a measure for supply chain collaboration. International Journal of Physical Distribution \& Logistics Management, 35 (1), 44-62.

https://doi.org/10.1108/09600030510577421

Simatupang, T.M., \& Sridharan, R. (2002). The collaborative supply chain. International Journal of logistics management, 13(1), 15-30. https://doi.org/10.1108/09574090210806333

Song, M., \& Di Benedetto, A. (2008). Supplier's involvement and success of radical new product development in new ventures. Journal of Operations Management, 26, 1-22. https://doi.org/10.1016/j.jom.2007.06.001

Spekman, R., Kammuf, J., \& Myhr, N. (1998). An empirical investigation into supply chain management: a perspective on partnerships. Supply Chain Management: An International Journal, 3(2), 53-67.

https://doi.org/10.1108/13598549810215379

Stank, T.P., Keller, S.B., \& Closs, D.J. (2001a). Performance benefits of supply chain integration. Transportation Journal, 41(2), 31-46. https://www.jstor.org/stable/20713491

Stank, T.P., Keller, S.B., \& Daugherty, P.J. (2001b). Supply chain collaboration and logistical service performance. Journal of Business Logistics, 22, 29-4. https:/ / doi.org/10.1002/j.2158-1592.2001.tb00158.x

Stone, M. (1974). Cross-Validatory Choice and Assessment of Statistical Predictions. Journal of the Royal Statistical Society, 36(2), 111-147. https://www.jstor.org/stable/2984809

Swink, M.L., Narasimhan, R., \& Wang, C. (2007). Managing beyond the factory walls: effects of four types of strategic integration on manufacturing plant performance. Journal of Operations Management, 25(1), 148-164. https://doi.org/10.1016/j.jom.2006.02.006 
Teece, D., Pisano, G., \& Shuen, A. (1997). Dynamic capabilities and strategic management. Strategic Management Journal, 18(7), 509-533. https://www.jstor.org/stable/3088148

Towers, N., \& Burnes, B. (2008). A composite framework of supply chain management and enterprise planning for small and medium-sized manufacturing enterprises. Supply Chain Management: An International Journal, 13(5), 349-355. https://doi.org/10.1108/13598540810894933

Van der Vaart, T., Giménez, C., \& van Donk, P.D. (2007). Supply chain integration and performance: the impact of business conditions. 14th International Annual EurOMA Conference (EurOMA), 25, 6.

Verona, G. (1999). A resource-based view of product development. Academy of Management Review, 24(1), 132-42. https://www.jstor.org/stable/259041

Vijayasarathy, L.R. (2010). Supply integration: an investigation of its multi-dimensionality and relational antecedents. International Journal of Production Economics, 124, 489-505. https://doi.org/10.1016/j.ijpe.2010.01.010

Ward, P., \& Zhou, H. (2006). Impact of Information Technology Integration and Lean/Just-In-Time Practices on Lead-Time Performance. Decision Science, 37(2), 173-203. https://doi.org/10.1111/j.1540-5915.2006.00121.x

Williams, B.D., Roh, J., Tokar, T., \& Swink, M. (2013). Leveraging supply chain visibility for responsiveness: The moderating role of internal integration. Journal of Operations Management, 31(7-8), 543-554. https://doi.org/10.1016/j.jom.2013.09.003

Wong, C.Y., Boon-itt, S., \& Wong, C.W.Y. (2011). The contingency effects of environmental uncertainty on the relationship between supply chain integration and operational performance. Journal of Operations Management, 29(6,) 604-615. https://doi.org/10.1016/j.jom.2011.01.003

Wong, W.Y., Lai, K.H., \& Bernroider, W.N. (2015). The performance of contingencies of supply chain information integration: The roles of product and market complexity. International Journal of Production Economics, 165, 1-11. https://doi.org/10.1016/j.ijpe.2015.03.005

Xue, X.L., Wang, Y.W., Shen, Q.P., \& Yu, G.Y. (2007). Coordination mechanism for construction supply chain management in the internet environment. International Journal of Project Management, 25, 150-157. https://doi.org/10.1016/j.ijproman.2006.09.006

Yu, W., Jacobs, M.A., Enns, D.W., \& Enns, H. (2013). The effects of supply chain integration on customer satisfaction and financial performance: An organizational learning perspective. International Journal of Production Economics, 146(1), 346-358. https://doi.org/10.1016/j.ijpe.2013.07.023

Zacharia, Z.G. (2009). An analysis of supply chain collaborations and their effect on performance outcomes. Journal of business logistics, 30(2), 101-123. https://doi.org/10.1002/j.2158-1592.2009.tb00114.x

Zhao, G., Feng, T., \& Wang, D. (2015). Is more supply chain integration always beneficial to financial performance? Industrial Marketing Management, 45, 162-172. https://doi.org/10.1016/j.indmarman.2015.02.015

Zhao, X., Huo, B., Selen, W., Hoi, J., \& Yeung, Y. (2011). The impact of internal integration and relationship commitment on external integration. Journal of Operations Management, 29(1-2), 17-32.

https://doi.org/10.1016/j.jom.2010.04.004

Zhao, X., Lynch, J.G., \& Chen, Q. (2010). Reconsidering Baron and Kenny: Myths and Truths about Mediation Analysis. Journal of Consumer Research, 37(2), 197-206. https://www.jstor.org/stable/10.1086/651257 


\section{Appendix 1}

\section{Measurement items (with factor loadings)}

Operational performance: Please indicate the level of company performance relatively to primary/major competitors ( 1 = strongly disagree; 5 = strongly agree $)$

\begin{tabular}{|l|r|}
\hline We can quickly introduce new products into the market & 0.874 \\
\hline We can quickly modify products to meet our major customer's requirements. & 0.831 \\
\hline We can quickly execute our urgent customer's orders. & 0.862 \\
\hline We can quickly respond to changes in market demand. & 0.917 \\
\hline The lead time for fulfilling customers' orders is short. & 0.680 \\
\hline
\end{tabular}

Supplier integration: Please indicate the extent of techniques or practices below between your organization and your majors suppliers $(1=$ not at all; $5=$ extensive $)$

\begin{tabular}{|l|r|}
\hline The level of using EDI (Electronic Data Interchange) in ordering & 0.816 \\
\hline The level of information systems linkage with our major suppliers & 0.904 \\
\hline The level of using conference call and video conference with major suppliers & 0.891 \\
\hline The level of using of Advanced Warehouse and cross-Docking solutions & 0.759 \\
\hline The level of sharing of demand forecast information & 0.822 \\
\hline The level of sharing of supply forecast and inventory level & 0.819 \\
\hline The degree of collaboration with supplier in product development and process improving & 0.783 \\
\hline The degree of collaboration with supplier to establish supply forecasting & 0.734 \\
\hline
\end{tabular}

Internal integration: Please indicate the extent of techniques or practices below within your organization $(1=$ not at all; 5 = extensive)

The level of using enterprise application integration among internal functions.

The use of the computer system for recording and managing the flow of material circulating inside the manufacturer 0.904

The use of kanban cards or RFID tag to manage the flow of material and product circulating inside the company 0.920

The degree of exploitation of ERP by staff in storage, processing, broadcasting and access to information.

The utilization of periodic interdepartmental meetings among internal functions. 0.736

The use of cross functional teams in new product development. 0.710

The degree of collaboration between departments in establishing sales forecasts, supply plans and production schedules. 0.790

The degree of commitment and collaboration between departments to resolve problems related to order fulfillment. 0.735

\begin{tabular}{|l|r|}
\hline \begin{tabular}{|l|} 
Customers integration: Please indicate the extent of techniques or practices below between your organization and \\
your majors suppliers ( $1=$ not at all; $5=$ extensive)
\end{tabular} & 0.842 \\
\hline The level of using EDI (Electronic Data Interchange) in ordering & 0.843 \\
\hline The level of information systems linkage with our major customers & 0.805 \\
\hline The use of barcode or RFID systems to record finished products and ensure traceability to the customer. & 0.794 \\
\hline The level of using of Advanced Warehouse and cross-Docking solutions & 0.832 \\
\hline The level of sharing of demand forecast information and inventory level with major customers. & 0.792 \\
\hline The degree of collaboration with customers in product development and process improving & 0.852 \\
\hline The degree of collaboration with customers to establish production schedules & 0.793 \\
\hline The degree of collaboration to jointly optimize inventory & \\
\hline
\end{tabular}




\section{Appendix 2}

Sample distribution

\begin{tabular}{|l|r|r|r|r|}
\hline \multirow{2}{*}{\multicolumn{1}{c}{ Industry }} & \multicolumn{2}{|c|}{ Sample } & \multicolumn{2}{c|}{ Respondents } \\
\cline { 2 - 5 } & Number & \multicolumn{1}{c|}{$\%$} & Number & \multicolumn{1}{c|}{$\%$} \\
\hline Automotive & 173 & 34.46 & 29 & 38.67 \\
\hline Aerospace & 60 & 11.95 & 12 & 16 \\
\hline Textile & 212 & 42.23 & 24 & 32 \\
\hline Electric/Electronic & 57 & 11.35 & 10 & 13.33 \\
\hline Total & 502 & $100 \%$ & 75 & $100 \%$ \\
\hline
\end{tabular}

\begin{tabular}{|l|r|r|}
\hline \multicolumn{1}{|c|}{ City } & Respondents & \multicolumn{2}{c|}{$\%$} \\
\hline Casablanca & 30 & 40 \\
\hline Tangier & 35 & 46.67 \\
\hline Other & 10 & 13.33 \\
\hline Total & 75 & 100 \\
\hline
\end{tabular}

Respondent's position distribution

\begin{tabular}{|l|r|r|}
\hline \multicolumn{1}{|c|}{ Respondent's position } & Number & \multicolumn{1}{c|}{$\%$} \\
\hline Plant manager & 14 & 18.67 \\
\hline Logistics manager/ supply chain manager & 20 & 26.67 \\
\hline Production manager/ Quality manager & 10 & 13.33 \\
\hline Import-export manager & 9 & 12.00 \\
\hline Sales manager & 7 & 9.33 \\
\hline Others & 15 & 20.00 \\
\hline Total & 75 & 100.00 \\
\hline
\end{tabular}

Journal of Industrial Engineering and Management, 2019 (www.jiem.org)

\section{(@) $(1) \Theta$}

Article's contents are provided on an Attribution-Non Commercial 4.0 Creative commons International License. Readers are allowed to copy, distribute and communicate article's contents, provided the author's and Journal of Industrial Engineering and Management's names are included. It must not be used for commercial purposes. To see the complete license contents, please visit https://creativecommons.org/licenses/by-nc/4.0/. 